\title{
Review
}

\section{Prevention of Cancer Through Lifestyle Changes}

\section{R. James Barnard}

\author{
Department of Physiological Science, University of California, Los Angeles, CA 90095, USA
}

\begin{abstract}
Cancer is the second leading cause of death in the USA and an abundance of evidence suggests that lifestyle factors including smoking, the typical high-fat, refined-sugar diet and physical inactivity account for the majority of cancer. This review focuses on diet and inactivity as major factors for cancer promotion by inducing insulin resistance and hyperinsulinemia. Elevated levels of serum insulin impact on the liver primarily, increasing the production of insulin-like growth factor I (IGF-I) while reducing the production of insulin-like growth factor binding protein 1 (IGFBP-1) resulting in stimulation of tumor cell growth and inhibition of apoptosis (programmed cell death). Adopting a diet low in fat and high in fiber-rich starch foods, which would also include an abundance of antioxidants, combined with regular aerobic exercise might control insulin resistance, reduce the resulting serum factors and thus reduce the risk for many different cancers commonly seen in the USA.
\end{abstract}

Keywords: diet - exercise - IGF-axis - insulin - p53

\section{Introduction}

Cancer is the second leading killer in the USA, accounting for $25 \%$ of all deaths. Prostate cancer is the most common cancer in males, followed by lung and colorectal. For women breast cancer is the most common, followed by lung and colorectal. However, it should be noted that lung cancer is the number one cancer killer for both men and women (1). An abundance of evidence suggests that lifestyle factors, including exposure to chemical carcinogens (smoking, etc.), diet and inactivity play a major role in the development of these common cancers. In order to understand how lifestyle changes might reduce the risk for the most common cancers we must first understand how cancer develops. Figure 1 shows a model explaining the development of cancer. We start with a normal cell with intact DNA. During the initiation stage something damages the DNA resulting in pre-neoplastic cells. Unfortunately, many chemicals in the environment are capable of inducing free radical formation to damage DNA in the body. Normal metabolism in the body may also generate free radicals. Thus, at any given time most, if not all, of us might have a number of pre-neoplastic cells. If we are

For reprints and all correspondence: R. James Barnard, PhD, Physiological Science, UCLA, 621 Charles E. Young Dr. So, Los Angeles, CA 90095-1606, USA. Tel: +1 310825 3794; Fax: +1 310206 9184; E-mail: jbarnard@physci.ucla fortunate, the damaged DNA sends a signal to genes such as p53 announcing the damage and increasing the protein products of these genes to stop the pre-neoplastic cell from dividing and hopefully repair the damaged DNA. If the repair does not work, the cell should be directed to apoptosis or programmed cell death. Since cancer is so common in the USA, the destruction of pre-neoplastic cells obviously does not always occur. This might be the result of defects in the p53 gene or the fact that the gene is suppressed by certain factors. Defects in the p53 gene have been identified in about half of all cancers, but these defects are usually observed in end-stage cancer. For prostate cancer all early-stage cancer has an intact $\mathrm{p} 53$ gene that is suppressed from acting, as we will discuss later. If the p53 gene does not eliminate the defective pre-neoplastic cell, the cell is stimulated to divide (promotion stage) by certain co-carcinogens, leading to the formation of a tumor.

Thus, to avoid cancer we should try to reduce the initiation stage by reducing exposure to many of the noxious chemical carcinogens present in our environment such as cigarette smoke, pesticides and many other commonly used household products. According to Ames (2), the typical Western diet also contains a variety of mutagens and carcinogens that may act through the generation of oxygen radicals and lead to the initiation of cancer as well as other degenerative diseases. A diet high in fat and/or refined sugar has been shown to induce

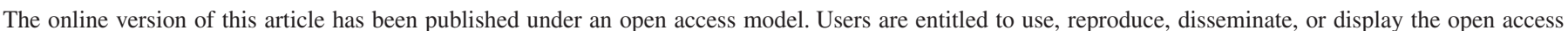
version of this article provided that: the original authorship is properly and fully attributed; the Journal and Oxford University Press are attributed as the original place of publication with the correct citation details given; if an article is subsequently reproduced or disseminated not in its entirety but only in part or as a derivative work this must be clearly indicated. 


\section{Tumor Development Model}

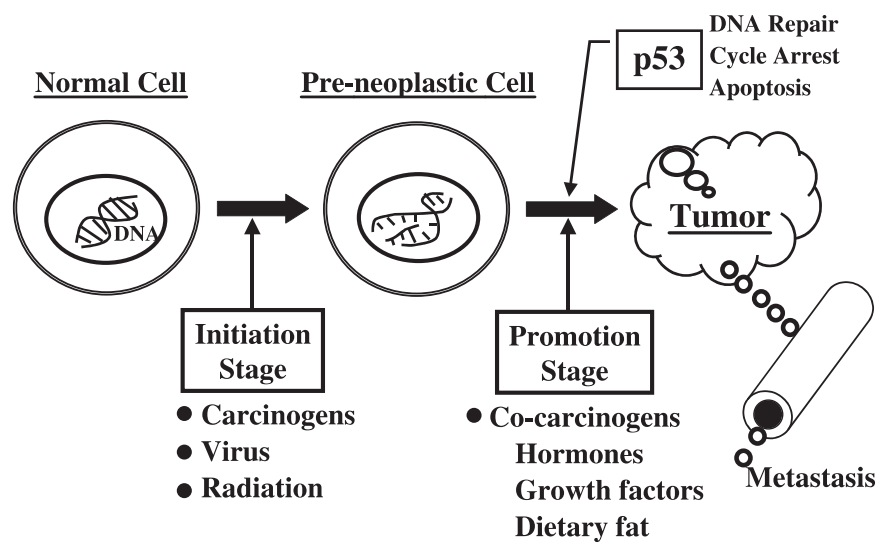

Figure 1. A model showing steps in the development of cancer.

oxidative stress (3-5). Consumption of red meat has been associated with cancers of the colon and rectum, breast and prostate. Whether it is the meat itself or the associated fat content is not known. Cooking meat at moderate to high temperatures forms carcinogenic heterocyclic amines, shown in animal studies to induce colon, breast and prostate cancer (6). Conversely, a diet high in whole grains, fruits and vegetables would contain large amounts of natural antioxidants that might play an important role in preventing free radical formation and cancer (2). This type of diet has been shown to reduce oxidative stress in the body (7). A diet high in whole grains, fruits and vegetables, especially if it includes an abundance of soy products would increase the intake of isoflavones, thought to reduce the risk of cancer (8). Genistein, the most abundant isoflavone in soy, has been shown in cell culture experiments to increase p21 and caspase 3 to cause cell cycle arrest and induce apoptosis of tumor cells (8). Consumption of soy might explain the large difference in many cancers between Western and Eastern cultures. Another factor that has been suggested to explain the difference is the consumption of green tea by Eastern cultures. Green tea contains epigallocatechin gallate, also shown to be protective in cell culture and animal studies (8). Attention has also been focused on the value of omega- 3 fatty acids found primarily in fish and certain nuts and seeds. These fatty acids block $C O X-2$ expression and reduce inflammation that has been implicated in the early stages and/or progression of prostate, breast and colon cancers (9-11). Conversely, omega-6 fatty acids found in meat and many vegetable oils increases $\mathrm{COX}-2$ expression. Recent studies have shown that non-steroidal antiinflammatory drugs (NSAIDs) that block the COX pathway reduce the development of adenomas, precursors of colon cancer, and reduce the risk for prostate cancer (12-14). Regular exercise has also been shown to increase the body's antioxidant mechanisms (15). In addition to preventing the initiation of cancer, diet and exercise may play an important role in reducing the promotion of cancer and inducing apoptosis by altering hormones such as insulin, testosterone and estrogen or growth factors such as insulin-like growth factor-I (IGF-I).

\section{Lung Cancer}

The link between smoking and lung cancer was established in the first Surgeon General's Report in 1964. However, a number of epidemiological studies have reported that exercise lowers the risk for lung cancer as reviewed by Lee (16). The large Norwegian study of 81516 men and women followed for 19 years reported a $25 \%$ reduction in lung cancer risk for men who walked or cycled for at least $4 \mathrm{~h}$ per week, after controlling for smoking habits and the number of cigarettes smoked (17). The mechanism by which exercise might reduce the risk for lung cancer has not been investigated but may be related to the ability of exercise to reduce serum insulin and subsequently IGF-I. This mechanism will be discussed in the section covering prostate cancer. IGF-I has been reported to be a risk factor for lung cancer (18). A high consumption of fruit and vegetables has also been associated with a reduced risk for lung cancer (19).

\section{Prostate Cancer}

Prostate cancer is the most common male cancer in the USA, but has a very low incidence in Asia. However, when Asian men migrate to the USA and adopt the US lifestyle the incidence of prostate cancer approaches that of US men, suggesting the involvement of lifestyle factors as opposed to a genetic difference (20). In addition, as the developing countries with a low incidence of prostate cancer become more Westernized, prostate cancer increases (21). The two lifestyle factors that have received the most attention are diet, especially the fat content, and being sedentary. The international data show a positive correlation between dietary fat and prostate cancer mortality with the lowest rates found in East Asian men and the highest rates found in US and European men (22). Most of the prospective cohort studies within a given population, however, have failed to show a relationship between dietary fat or fatty food consumption and prostate cancer risk as discussed by Moyad (23). The negative results from the cohort studies may be due to the fact that in any given population there is little variation in the dietary fat consumption, or may be due to the inability of questionnaires to accurately measure habitual fat consumption. Another possibility is a variation in the type of fat consumed. Current evidence implicates omega- 6 fatty acids in the promotion of cancers and omega- 3 polyunsaturated fatty acids and omega- 9 monounsaturated fatty acids as being protective (24). It may also be that in the international data not only do men with a low incidence of prostate cancer mortality consume much lower fat diets, they also tend to be more physically active. Epidemiological studies have reported that increased physical activity can reduce the risk for prostate, and other forms of cancer, in US and European men. In a recent review of the literature on physical activity and the risk for prostate cancer, Thune and Furberg (25) found that 14 of 28 epidemiological studies reported that increased occupational or leisure-time activity reduced the risk for prostate cancer by $10-70 \%$. 
In order to investigate possible mechanisms involved in the roles that diet and exercise play in the progression of prostate cancer, Tymchuk et al. (26) developed a bioassay using serum to stimulate prostate cancer cells in culture. By placing men on a low-fat diet consisting primarily of grains, fruits and vegetables, and regular, supervised exercise they examined serum changes in vivo and their effect on prostate cancer cell growth in vitro. The subjects were participants or employees from the Pritikin Longevity Center Residential Program. During their stay at the Center, food was prepared and served buffet style to the participants and consisted of $10-15 \%$ of calories from fat (polyunsaturated/saturated fatty acid ratio $=1.24), 15-20 \%$ of calories from protein, and $65-75 \%$ of calories from carbohydrates, primarily unrefined. Carbohydrates were in the form of high-fiber whole grains and other complex carbohydrates ( $\geq 5$ servings/day), vegetables ( $\geq 4$ servings/day), and fruits ( $\geq 3$ servings/day). Protein was primarily derived from plant sources with non-fat dairy allowed for up to 2 servings/day. Fish or fowl was served in 3.5 ounce portions 1 day/week and in soups or casseroles 2 days/week. The diet contained $<100 \mathrm{mg}$ of cholesterol per day and alcohol, tobacco and caffeinated beverages were not allowed during the program. Prior to starting the exercise training, subjects underwent a graded treadmill stress test. Based on the results, the subjects were provided with an appropriate training heart rate value and given an individualized walking program. The exercise regimen consisted of daily walking at the training heart rate for 45-60 min.

In the initial study Tymchuk et al. (26) found that just 11 days of the low-fat diet and exercise program reduced serum-stimulated LNCaP prostate cancer cell growth by $30 \%$. Serum samples obtained from men (employees) who had adhered to the low-fat diet and exercise program for an average of 14 years showed an additional 15\% reduction in $\mathrm{LNCaP}$ cell growth. $\mathrm{LNCaP}$ is a well-established, androgen-dependent cell line, developed from a patient with prostate cancer. When the serum samples from the men following the low-fat diet and exercise program were used to stimulate $\mathrm{PC}-3$ cells, an androgenindependent cell line typical of advanced prostate cancer, no reduction in cell growth was found (26). In a subsequent study Ngo et al. (27) confirmed the diet and exercise reduction in LNCaP cell growth using another androgen-dependent, patientderived cell line, LAPC-4. A control group of similar aged men without any intervention were studied over an 11-day period and no change in LNCaP cell growth was found.

In an earlier study Tymchuk et al. (28) had reported that men attending the Pritikin Longevity Center low-fat diet and exercise program had significant reductions in serum insulin and significant elevations in sex hormone-binding globulin. The increase in SHBG should lower the serum levels of free testosterone and estradiol, and might be a factor in the reduction in LNCaP cell growth observed following diet and exercise as this cell line is androgen dependent and has a mutated androgen receptor that binds both testosterone and estradiol. Tymchuk et al. $(26,29)$ confirmed the reduction in serum free testosterone in the Pritikin participants and subsequently reported that insulin, testosterone and estradiol could individually stimulate the growth of LNCaP cells. However, when these hormones were added individually, or in combination, to the post diet and exercise serum they could only account for half of the reduction in LNCaP cell growth, indicating the involvement of other important factors.

Barnard et al. (30) developed a model similar to Figure 2 and started to investigate IGF-1 and its binding proteins. The IGF axis consists of IGF-I, IGF-II, six different binding proteins (IGFBP 1-6) and two receptors, IGF-IR and IGF-IIR. IGF-I is a peptide growth factor produced by the liver and other tissues, and is known to play a pivotal role in regulating cell growth, differentiation and apoptosis (programmed cell death) $(18,31)$. It is also a potent mitogen for most tissues including the prostate (18,31). According to Yarak et al. (32) $75 \%$ of the circulating IGF-I comes from the liver. IGF-I activity is regulated by the six different binding proteins. IGFBP-3 is the most abundant and binds $90 \%$ of the circulating IGF-I but is not affected by different metabolic states and Ngo et al. (33) found no change in IGFBP-3 with the diet and exercise program. Conversely, IGFBP-1 is regulated by the metabolic state, being highest following fasting.

Ngo et al. (33) found that the low-fat diet and exercise program decreased not only the fasting serum level of insulin, but also IGF-I while increasing IGFBP-1. These changes in serum levels of IGF-I and IGFBP-1 are thought to be due to the changes in serum insulin and its impact on the liver. Phillips et al. (34) reported that insulin stimulated the production of IGF-I by hepatocytes. When Ngo et al. (27) added IGF-I back to the diet and exercise serum, the reduction in $\mathrm{LNCaP}$ cell growth was completely eliminated. When IGFBP-1 was added to the baseline serum, they observed a significant reduction in $\mathrm{LNCaP}$ cell growth. In addition to being a regulator of cell growth, IGF-I has been reported to be a suppressor of apoptosis in several different studies (35). Ngo et al. (27) studied apoptosis in their cell culture system using two different methods, Annexin-V and TUNEL. They also used propidium iodide stain to detect necrotic cells. Almost no apoptotic or

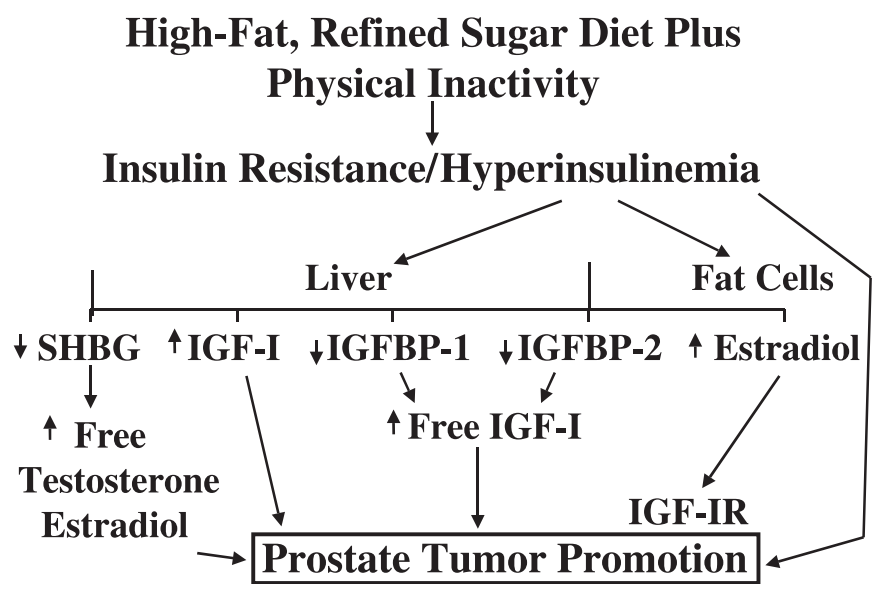

Figure 2. A model explaining the role of diet and a sedentary lifestyle in the development of prostate cancer [after Barnard et al. (30)]. 
necrotic cells were found in the fetal bovine serum (FBS) control or the pre diet and exercise samples. However, both the Annexin-V and TUNEL staining methods showed a significant increase in apoptosis in the post diet and exercise-serumstimulated samples. The fact that very little apoptosis was observed in the control serum-stimulated LNCaP cells may be the result of the high levels of IGF-I and low levels of IGFBP-1 in the control serum and may help to explain why prostate cancer is so prevalent in the USA.

In an attempt to separate out the individual effects of diet versus exercise observed in their earlier studies with the androgen-dependent prostate cancer cell lines, Barnard et al. (36) obtained serum samples from men who had been involved in the Adult Fitness Program at the University of Nevada, Las Vegas. The men were matched in age with a control group of men on no diet or exercise program, and for age and duration of participation to the long-term diet and exercise subjects previously studied. Volunteers were requested who had participated in the program for at least 10 years; the average was 14.7 years. The program was held 5 days per week for $1 \mathrm{~h}$ and consisted of warm-up and flexibility activities followed by 45-50 min of continuous, strenuous exercise including calisthenics and swimming laps in the pool. There was no dietary intervention in the UNLV Adult Fitness Program. Serum insulin and IGF-I were lower in the exercise and diet + exercise groups compared to controls, but were not significantly different from each other. IGFBP-1 was higher in both the exercise and the diet + exercise groups compared to controls and was significantly higher in the diet + exercise group compared to the exercise group.

When the serum was used to stimulate the $\mathrm{LNCaP}$ cells in culture, growth was reduced in both the exercise $(65 \%$ FBS control) and diet + exercise (55\% FBS control) groups compared to the control group where the growth was $99 \%$ of the FBS. They then examined apoptosis in the cell cultures using Annexin- $V$ and TUNEL. The staining results from the two methods demonstrated that exercise as well as diet and exercise intervention increases apoptosis in the LNCaP cells. When the slides from the TUNEL staining were quantitatively analyzed, almost twice as much apoptosis was found in the diet and exercise samples compared to the exercise-only samples. The fact that apoptosis was higher in the diet + exercise subjects is in agreement with the significantly higher IGFBP-1 levels compared to the exercise-only group.

In an attempt to focus on the possible mechanisms involved in the reduction in $\mathrm{LNCaP}$ cell growth and increased apoptosis observed in the exercise-serum-stimulated samples, Leung et al. (37) turned their attention to the action of the p53 gene. Several studies have shown that IGF-1 suppresses the action of p53 that is phosphorylated and stabilized when defects are found in DNA. The increase in p53 protein normally activates other genes or factors to cause cell cycle arrest, DNA repair or to induce apoptosis (34). The serum-stimulated cell cultures were lysed, centrifuged and the supernatant analyzed for p53 protein and was found to be significantly increased in the lysates from the exercise-serum-stimulated $\mathrm{LNCaP}$ cells compared to controls. These results also demonstrate that the LNCaP cells have an intact p53 pathway that is suppressed with serum from control subjects. According to Gurumurthy et al. (35) an intact p53 pathway is characteristic of all early stage prostate cancer. In end-stage prostate cancer defects have been reported in the p53 gene.

To further investigate the involvement of the p53 pathway in the exercise-serum-stimulated LNCaP cell growth reduction and induction of apoptosis, Leung et al. (37) utilized another cell line, LN-56. LN-56 is a LNCaP-derived cell line in which p53 was rendered non-functional by expression of a dominant negative fragment of $\mathrm{p} 53$, known as genetic suppressor element 56. The results from the growth assay showed no significant difference between the control and exercise groups when the serum was used to stimulate the cells. The exercise-serumstimulated growth in the LN-56 cells was $91 \%$ of the FBS control compared to $65 \%$ of FBS control for the LNCaP cells. When they examined apoptosis in the LN-56 cells, the exerciseserum-stimulated cells showed half the apoptosis observed with the control-serum-stimulated cells. This was opposite to the response observed in the LNCaP cells where apoptosis was greatly increased in the exercise-serum-stimulated cells. Collectively, the results from these experiments indicate that the reduction in serum IGF-I and increase in IGFBP-1 resulting from adopting a very-low-fat diet and/or regular exercise allows the prostate tumor cells to stabilize the p53 protein and activate downstream effectors to reduce cell growth and induce apoptosis. These data also provide a mechanism to explain the epidemiological data showing a reduction in the risk for prostate cancer in men who take part in regular exercise (25).

If the observations of reduced cell growth and the induction of apoptosis reported for the cell culture studies with androgendependent prostate cancer cell lines also occur in the body, then a very-low-fat diet and exercise program might be of value in the treatment of prostate cancer patients, especially those with early-stage cancer. In order to investigate the possible effectiveness of a very-low-fat diet and exercise program on prostate cancer patients, Ornish and colleagues $(38,39)$ randomized a group of men on 'watchful waiting' to control or to diet and exercise intervention. Both groups received standard medical care from their personal physicians. The patient all had biopsy-documented prostate cancer, PSA ranging from 4 to $10 \mathrm{ng} / \mathrm{ml}$, and a Gleason sum of $<7$ prostate adenocarcinoma. The men in the diet and exercise intervention group were prescribed a vegan diet with $10 \%$ of calories from fat supplemented with soy, $3 \mathrm{~g} /$ day fish oil (omega-3 fatty acid) and $400 \mathrm{IU} /$ day vitamin $\mathrm{E}$. The exercise was to be aerobic (walking, jogging etc.) for 30-60 min 6 days/week. Patients were also encouraged to practice stress management techniques including yoga, breathing, imagery etc. for $1 \mathrm{~h} /$ day.

After 1 year, changes in serum PSA were small but statistically significant, with the control group showing an increase and the diet and exercise group showing a drop. Also, at the end of 1 year, six of 43 in the control group had gone on for conventional treatment due to rising PSA while none of the 41 in the diet and exercise group had treatment. There was very high 
adherence to the diet and exercise program and even some in the control group had made significant lifestyle changes. Serum samples from these patients were used in the LNCaP cell bioassay. Compared to baseline, cell growth was reduced by $9 \%$ in the control group and by $60 \%$ in the diet and exercise group. The growth rate in the baseline samples was not significantly different from what had previously been observed with serum from men without prostate cancer. The study is progressing with a plan to follow the patients for 5 years.

\section{Breast Cancer}

Breast cancer is the most common female cancer in the USA and, like prostate cancer, is hormone-dependent in the early stages. The influence of lifestyle factors in breast cancer is supported by the large international variation and the migration studies $(40,41)$. Even though breast cancer is initially an estrogen-dependent cancer, most breast cancer occurs in postmenopausal women. With the menopause estrogen levels drop but do not completely disappear as estrogen is produced via aromatase activity, primarily in fat cells. Thus, it is not surprising that obesity is a risk factor for postmenopausal breast cancer. Elevated serum estradiol has also been shown to be a risk factor for breast cancer in postmenopausal women (42). Like prostate cancer, the international data show a strong, positive correlation between per capita fat consumption and breast cancer incidence and mortality (40). Epidemiological studies in countries with a high incidence of breast cancer, such as the USA, have shown that regular exercise reduces the risk for breast cancer. In their review, Thune and Furberg (25) reported that occupational or leisure time physical activity reduced the risk for breast cancer in 26 of 41 studies by $30 \%$ in pre-, peri- and postmenopausal women. In 16 of 28 studies a graded dose-response relationship was reported.

Heber et al. (43) studied postmenopausal women attending the Pritikin Center and reported that the 3-week, low-fat diet and exercise program lowered serum estradiol from $18.1 \pm 3.6$ to $9.4 \pm 2.4 \mathrm{pg} / \mathrm{ml}$. In a subsequent study (44) they reported serum changes in premenopausal women placed on the Pritikin diet for 2 months at the UCLA Clinical Research Center. There was no change in menstrual cycle duration or the phases of the cycle. However, serum estradiol was reduced by $25 \%$ during the follicular phase and by $22 \%$ during the leuteal phase while serum estrone was reduced by 19 and $18 \%$, respectively, during the two phases. Progesterone and sex hormone-binding globulin (SHBG) were unchanged. SHBG, produced primarily in the liver, regulates the amount of free hormone available to interact with the hormone receptors. Insulin suppresses the production of SHBG by the liver. In a more recent study (45) with postmenopausal women attending the Pritikin 3-week diet and exercise program, serum insulin was reduced by $39 \%$ and SHBG increased by $39 \%$ in women on hormone replacement therapy (HRT). In women not on HRT, insulin was reduced by $19 \%$ and SHBG increased by $42 \%$. The drop in insulin may be very important as insulin has been reported to be a risk factor for both estrogen positive and negative breast cancer (46). Barnard RS,
Liva M, Ngo TM, Varr BC and Hong J (unpublished) recently studied changes in the IGF axis in postmenopausal women attending the Pritikin Program. In 18 women on HRT, IGF-I was reduced from $170 \pm 22$ to $142 \pm 13 \mathrm{pg} / \mathrm{ml}$ and IGFBP-1 was increased from $55 \pm 8$ to $71 \pm 10 \mathrm{pg} / \mathrm{ml}$ while insulin was reduced from $14.5 \pm 2$ to $9.1 \pm 1 \mu \mathrm{IU} / \mathrm{ml}$. These changes in the IGF axis are important as IGF-I has been reported to be a risk factor for breast cancer and it is now well established that there is interaction between the IGF and estrogen receptor pathways in breast cancer $(18,47)$.

\section{Colorectal Cancer}

Cancer of the colon and/or rectum is the second leading cause of cancer deaths in the USA and is the third most common cancer in both men and women. Over the years there has been a lot of controversy regarding the involvement of lifestyle factors in intestinal cancer. This may be due, in part, to different site-specific etiologies of the cancer. Like the previous two cancers, colorectal cancer shows a large international variation that Armstrong and Doll (40) attributed to the variation in dietary fat consumption. Prior to this, Burkitt (48) suggested that other dietary factors such as fiber and refined sugar played a more important role. He suggested that the removal of fiber by refining carbohydrates reduced stool bulk and increased transit time as well as adversely affecting intestional flora.

Adenomas are precursor lesions of colorectal cancer and are informative endpoints for assessing cancer risk. Ten case-control studies reviewed by Peters et al. (49) showed inverse associations between fiber intake and colorectal adenoma. On the other hand, large cohort studies have been less convincing. Studies in the USA, Finland and Sweden reported no protective effect of fiber (50-52). One large cohort study in US men, the Health Professionals Follow-up Study, did find a significant inverse association of distal adenomas and soluble but not insoluble fiber intake (53). The exact reason for the inconsistency in the cohort studies is not known but may be due to the fact that the populations have been rather homogeneous with relatively low fiber intakes or may be due to the inability of food questionnaires to accurately predict habitual fiber intake. The recent European Prospective Investigation into Cancer and Nutrition (EPIC) study involved 519978 individuals with fiber intakes that ranged from $13 \mathrm{~g} /$ day for the lowest quintile to $34 \mathrm{~g} / \mathrm{day}$ for the highest quintile (54). Comparing the highest to the lowest quintile of fiber intake they found a relative risk for large bowel cancer of 0.75 . Even this intake of $34 \mathrm{~g} /$ day was lower that the $50+\mathrm{g} /$ day originally described by Burkitt. After evaluating the scientific evidence, the European Cancer Prevention Consensus Panel concluded in 1998 that there was good evidence to support the protective effect of fiber against colon (and breast) cancer (55).

Burkitt originally suggested that removing fiber by processing carbohydrates would affect bowel function. This would also lead to insulin resistance and hyperinsulinemia. Two recent papers have suggested that hyperinsulinemia resulting from consumption of high-fat, refined-sugar diets may be an 
important factor in the etiology of colorectal cancer $(56,57)$. This might be related to our proposed model for prostate cancer as IGF-I has also been found to be a risk factor for colon cancer (18). A high-fat diet (corn oil) has also been reported to increase colon mucosa IGF-I receptors in rats (58). The involvement of hyperinsulinemia and elevated IGF-I might also be related to the epidemiological studies showing a reduction in intestinal cancer with increased physical activity. According to Friedenreich and Orenstein (59), the most definitive evidence for an association between physical activity and cancer exists for colon cancer. Of 51 studies on colon or colorectal cancer, 43 demonstrated a reduction in risk in the most physically active men and women with an average reduction of $40-50 \%$ and values as high as $70 \%$ for the most physically active. Slattery et al. (60) recently examined the relationship between lifestyle factors and p53 mutations in colon tumors. They concluded that a Western-style diet high in refined sugar and red meat was correlated with p53 mutations while no association was found with physical activity. This, to our knowledge, is the first study to show a relationship between diet and p53 mutations, Whether or not a Westernstyle diet can cause p53 mutations remains to be demonstrated.

Reddy et al. (61) studied colon cancer risk factors in eight women attending the Pritikin Program by collecting stool samples over 2 days and diet records over 3 days before the start and at the end of the 3-week program. Dietary fat intake decreased from 34 to $7 \%$ of calories and fiber increased from 17 to $37 \mathrm{~g}$ /day during the residential program. Stool weight increased from 86 to $145 \mathrm{~g}$ /day. Total stool bile acid was reduced from $9.7 \pm 2$ to $4.5 \pm 1 \mathrm{mg} / \mathrm{g}$ dry weight. More important was the very significant reduction in the secondary bile acids, deoxycholic and lithocholic acid that suggests a change in the intestinal flora. The reduction in secondary bile acids should be important as they are thought to be the most carcinogenic bile acids (62). Intervention trials with bran, soluble fiber or vegetables have not reduced recurrence rates of adenomatous colorectal polyps (63-65). Going back to Burkitt's original work, not only did the African natives have a very low incidence of colorectal cancer with a high fiber intake, they also consumed a very-low-fat diet and were very physically active. Thus, it may be that total lifestyle modification is needed to reduce cancer risk, not simply modification of one aspect.

\section{Conclusion}

In his presidential address to the American Cancer Society in 1966, Joseph Burchenal (66) suggested that the study of one form of cancer might provide guide-posts to the understanding of another related form of cancer. This suggestion seems to relate to hyperinsulinemia, the IGF axis and their associations with several forms of cancer. However, the true unifying factor for most cancers seems to be lifestyle: smoking, a high-fat and refined-sugar diet along with a lack of physical activity. These lifestyle factors can easily be changed and may prevent most types of cancer. By adopting a diet consisting primarily of whole grains, fruits and vegetables with limited amounts of

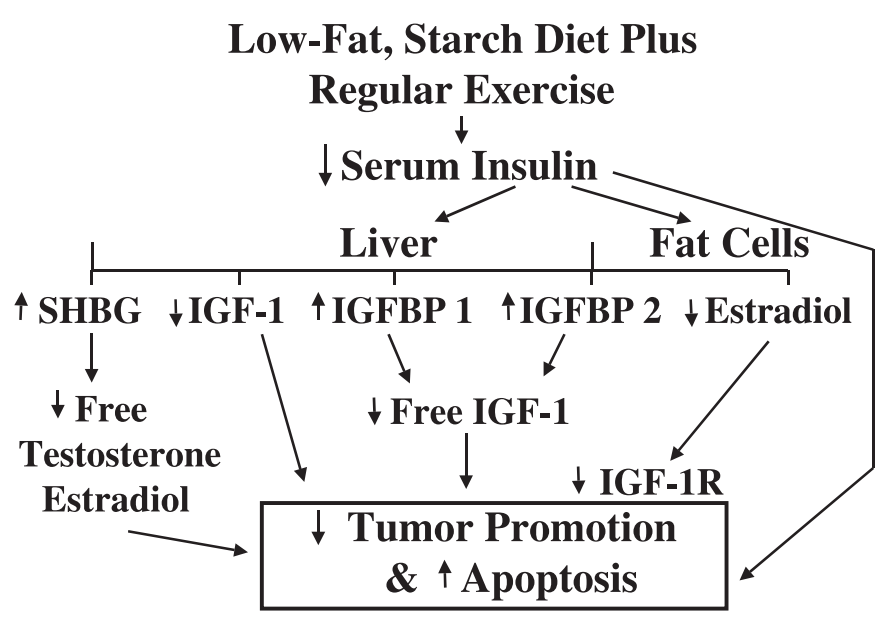

Figure 3. A model explaining how a change in lifestyle to include a low-fat, high-fiber diet plus regular exercise might reduce the risk for cancer.

meat, primarily chicken or cold-water fish, and doing 45-60 min of daily exercise, one could achieve significant changes in hormones and growth factors known to be associated with cancer as shown in Figure 3. Primary prevention trials to test this hypothesis are difficult to conduct due to the large number of subjects, the prolonged time required and the cost. However, secondary prevention trials like the Ornish study $(38,39)$ with prostate cancer or the colorectal adenoma recurrence studies may provide important scientific evidence for the value of these lifestyle changes.

Dr James Barnard is a consultant at the Pritikin Longevity Center.

\section{References}

1. Cancer Facts \& Figures. American Cancer Society, 2004. Atlanta, GA.

2. Ames BN. Dietary carcinogens and anticarcinogens. Oxygen radicals and degenerative diseases. Science 1983;221:1256-64.

3. Faure P, Rossini E, Lafond JL, Richard MJ, Favier A, Halimi S. Vitamin E improves the free radical defense system potential and insulin sensitivity of rats fed high fructose diets. J Nutr 1977;127:103-7.

4. Slim RM, Toborek M, Watkins BA, Boissonneault GA, Henning B. Susceptibility to hepatic oxidative stress in rabbits fed different animal and plant fats. J Am Coll Nutr 1996;15:289-94.

5. Roberts CK, Vasiri ND, Wang XQ, Barnard RJ. Enhanced NO inactivation and hypertension induced by a high-fat, refined-carbohydrate diet. Hypertension 2000;36:423-9.

6. Strickland PT, Qian Z, Friesen MD, Rothman N, Sinha R. Metabolites of 2-amino-1-methly-1phenylimidazol(4,5-b)pyridine (PhiP) in human urine and after consumption of charbroiled or fried beef. Mutat Res 2002;506-507:163-73.

7. Roberts CK, Vasiri ND, Barnard RJ. Effect of diet and exercise intervention on blood pressure, insulin, oxidative stress, and nitric oxide availability. Circulation 2002;106:2530-2.

8. Park OJ, Surh Y-J. Chemoprotective potential of epigallocatechin gallate and genistein: evidence from epidemiological and laboratory studies. Toxicol Lett 2004;150:43-56.

9. Singh J, Hamid R, Reddy BS. Dietary fat and colon cancer: modulation of cyclooxygenase- 2 by types and amount of dietary fat during the postinitiation stage of colon carcinogenesis. Cancer Res 1997;57:3465-70.

10. Badawi AF, El-Sohemy A, Ghoshal AK, Archer MC. The effect of dietary n-3 and n-6 polyunsaturated fatty acids on the expression of cyclooxygenase 1 and 2 and levels of p21 ras in rat mammary glands. Carcinogenesis 1998;19:903-10. 
11. Nelson WG, De Marzo AM, Isaacs WB. Prostate cancer. $N$ Engl J Med 2004;349:366-81.

12. Sandler RS, Halabi S, Baron JA, et al. A randomized trial of aspirin to prevent colorectal adenomas in patients with previous colorectal cancer. N Engl J Med 2003;348:883-90.

13. Baron JA, Cole BF, Sandler RS, et al. A randomized trial of aspirin to prevent colorectal adenomas. $N$ Engl J Med 2003;348:891-9.

14. Lin DW, Nelson PS. The role of cyclooxygenase-2 inhibition for the prevention and treatment of prostate cancer. Clin Prostate Cancer 2003;2:119-26.

15. Ji LL. Exercise-induced modulation of antioxidant defense. Ann NY Acad Sci 2002;959:82-92.

16. Lee IM. Physical activity and cancer prevention—data from epidemiologic studies. Med Sci Sports Exerc 2003;35:1823-7.

17. Thune I, Lund E. The influence of physical activity on lung-cancer risk: a prospective study of 81,516 men and women. Int J Cancer 1997;70:57-62.

18. Yu H, Rohan T. Role of the insulin-like growth factor family in cancer development and progression. J Natl Cancer Inst 2000;92:1472-89.

19. Ziegler RG, Mayne ST, Swanson CA. Nutrition and lung cancer. Cancer Cause Control 1996;7:157-77.

20. Shimizu H, Ross RK, Bernstein L, Yatani R, Henderson BE, Mack TM. Cancers of the prostate and breast among Japanese and white immigrants in Los Angeles County. Br J Cancer 1991;63:963-6.

21. Hsing AW, Tsao L, Devesa SS. International trends and patterns of prostate cancer incidence and mortality. Int J Cancer 2000;85:60-7.

22. Hebert JR, Hurley TG, Olendzki BC, Teas J, Ma Y, Hampl JS. Nutritional and socioeconomic factors in relation to prostate cancer mortality: a cross-national study. J Natl Cancer Inst 1998;87:1437-47.

23. Moyad MA. Dietary fat reduction to reduce prostate cancer risk: controlled enthusiasm, learning a lesson from breast or other cancers, and the big picture. Urology 2002;59:51-62.

24. Bartsch H, Nair J, Owen RW. Dietary polyunsaturated fatty acids and cancers of the breast and colorectum: emerging evidence for their role as risk modifiers. Carcinogenesis 1999;20:2209-18.

25. Thune I, Furberg AS. Physical activity and cancer risk: dose-response and cancer, all sites and site-specific. Med Sci Sports Exerc 2001;33:S530-50.

26. Tymchuk CN, Barnard RJ, Heber D, Aronson WJ. Evidence of an inhibitory effect of diet and exercise on prostate cancer cell growth. J Urol 2001;166:1185-9.

27. Ngo TH, Barnard RJ, Leung P-S, Cohen P, Aronson WJ. Insulin-like growth factor I (IGF-I) and IGF binding protein-1 modulate prostate cancer cell growth and apoptosis: Possible mediators for the effects of diet and exercise on cancer cell survival. Endocrinology 2003;144:2319-24.

28. Tymchuk CN, Tessler SB, Aronson WJ, Barnard RJ. Effects of diet and exercise on insulin, sex hormone-binding globulin, and prostate-specific antigen. Nutr Cancer 1998;31:127-31.

29. Tymchuk CN, Barnard RJ, Ngo TH, Aronson WJ. The role of testosterone, estradiol, and insulin in diet and exercise-induced reductions in prostate cancer cell growth in vitro. Nutr Cancer 2002;42:112-6.

30. Barnard RJ, Aronson WJ, Tymchuk CN, Ngo TH. Prostate cancer: another aspect of the insulin-resistance syndrome? Obesity Rev 2002;3:303-8.

31. LeRoith D, Roberts CT Jr. The insulin-like growth factor system and cancer. Cancer Lett 2003;195:127-37.

32. Yarak S, Liu JL, Stannard B, et al. Normal growth and development in the absence of hepatic insulin-like growth factor I. Proc Natl Acad Sci USA 1999;96:7324-9.

33. Ngo TH, Barnard RJ, Tymchuk CN, Cohen P, Aronson WJ. Effect of diet and exercise on serum insulin, IGF-I, and IGFBP-1 levels and growth of LNCaP cells in vitro. Cancer Causes Control 2002;13:929-35.

34. Phillip LS, Goldstein S, Pao CI. Nutrition and somatomedin. XXVI. Molecular regulation of IGF-I by insulin in cultured rat hepatocytes. Diabetes 1991;40:1525-30.

35. Gurumurthy S, Vasudevan KM, Rangnekar VM. Regulation of apoptosis in prostate cancer. Cancer Metastasis Rev 2001;20:225-43.

36. Barnard RJ, Ngo TH, Leung P-S, Aronson WJ, Golding LA. A Low-fat diet and/or strenuous exercise alters the IGF axis in vivo and reduces prostate tumor cell growth in vitro. Prostrate 2003;56:201-6.

37. Leung P-S, Aronson WJ, Ngo TH, Golding LA, Barnard RJ. Exercise alters the IGF axis in vivo and increases $\mathrm{p} 53$ protein in prostate tumor cells in vitro. J Appl Physiol 2004;96:450-4.

38. Ornish D, Lee KL, Fair WR, Pettengill EB, Carroll PR. Dietary trial in prostate cancer: Early experience and implications for clinical trial design. Urology 2001;57:200-1.
39. Ornish D, Carroll PR, Fair WR, et al. Can intensive lifestyle changes affect the progression of prostate cancer? J Urol (in press).

40. Armstrong B, Doll R. Environmental factors and cancer incidence and mortality in different countries, with special reference to dietary practices. J Cancer 1975;15:617-31.

41. Ziegler RG, Hoover RN, Pike MC, et al. Migration patterns and breast cancer risk in Asian-American women. J Natl Cancer Inst 1993;85:1819-27.

42. Hankinson SE, Willett WC, Manson JE, et al. Plasma sex steroid hormone levels and risk of breast cancer on postmenopausal women. J Natl Cancer Inst 1998;90:1292-9.

43. Heber D, Ashley JM, Leaf DA, Barnard RJ. Reductioin of serum estradiol in postmenopausal women given free access to low-fat high-carbohydrate diet. Nutrition 1991;7:137-41.

44. Bagga D, Ashley JM, Geffrey SP, et al. Effects of a very low fat, high fiber diet on serum hormones and menstrual function. Cancer 1995;76:2491-6.

45. Tymchuk CN, Tessler SB, Barnard RJ. Changes in sex hormone-binding globulin, insulin, and serum lipids in postmenopausal women on a lowfat, high-fiber diet combined with exercise. Nutr Cancer 2000;38:158-62.

46. Hirose K, Toyama T, Iwata H, Takezaki T, Hamajima N, Tajima K. Insulin, insulin-like growth factor and breast cancer risk in Japanese women. Asian Pac J Cancer Prev 2003;4:239-46.

47. Hamelers IHL, Steenbergh PH. Interactions between estrogen and insulinlike growth factor signaling pathways in human breast tumor cells. Endocr Relat Cancer 2003;10:331-45.

48. Burkitt DP. Related diseases-related cause? Lancet 1969;II:1229-31.

49. Peters U, Sinha R, Chatterjee N, et al. Dietary fiber and colorectal adenoma in a colorectal cancer early detection programme. Lancet 2003;361:1491-5.

50. Fuchs CS, Giovannucci E, Colditz GA, et al. Dietary fiber and the risk of colorectal cancer and adenoma in women. N Engl J Med 1999;340:169-76.

51. Terry P, Giovannucci E, Michels KB, et al. Fruit, vegetables, dietary fiber, and risk of colorectal cancer. J Natl Cancer Inst 2001;93:525-33.

52. Peitinen P, Malila N, Virtanen M, et al. Diet and risk of colorectal cancer in a cohort of Finnish men. Cancer Causes Control 1999;10:387-96.

53. Platz EA, Giovannucci E, Rimm EB, Stampfer MJ, Colditz GA, Willett WC. Dietary fiber and distal colorectal adenoma in men. Cancer Epidemiol Biomarkers Prev 1997;6:661-70.

54. Bingham SA, Day NE, Luben R, et al. Dietary fiber in food and protection against colorectal cancer in the European Prospective Investigation into Cancer and Nutrition (EPIC): an observational study. Lancet 2003;361:1496-501.

55. Hill M. Dietary fiber and colon cancer: where do we go from here? Proc Nutr Soc 2003;62:63-5.

56. Giovannucci E. Diet, body weight, and colorectal cancer: a summary of the epidemiologic evidence. $J$ Womens Health 2003;12:173-82.

57. Komninou D, Ayonote A, Richie JP Jr, Rigas B. Insulin resistance and its contribution to colon carcinogenesis. Exp Biol Med 2003;228:396-405.

58. Zhang W, Thornton WH Jr, MacDonald RS. Insulin-like growth factor-I and II receptor expression in rat colon mucosa are affected by dietary lipid intake. J Nutr 1998;128:158-65.

59. Friedenreich CM, Orenstein MR. Physical activity and cancer prevention: etiologic evidence and biological mechanisms. J Nutr 2002;132: 3456S-64S.

60. Slattery ML, Curtin K, Ma K, et al. Diet, activity, and lifestyle associations woth p53 mutations in colon tumors. Cancer Epidemiol Biomark Prev 2002;11:541-8.

61. Reddy BS, Engle A, Simi B, Barnard RJ, Pritikin N, Wynder EL. Effect of low-fat, high-carbohydrate diet on fecal bile acids and neutral sterols. Prevent Med 1988;17:432-9.

62. Earnest DL, Einspahr JG, Alberts DS. Protective role of wheat bran fiber: data from biomarker trials. Am J Med 199;106:32S-37S.

63. Schatzkin A, Lanza E, Corle D, et al. Lack of effect of a low-fat, highfiber diet on the recurrence of colorectal adenomas. $N$ Engl J Med 2000;342:1149-55.

64. Alberts DS, Martinez ME, Roe DJ, et al. Lack of effect of a high-fiber cereal supplement on the recurrence of colorectal adenomas. Phoenix colon cancer prevention physicians' network, $N$ Engl J Med 2000;342:1156-62.

65. Bonithon-Kopp C, Kronborg O, Giacosa A, Rath U, Faivre J. Calcium and fiber supplementation in prevention of colorectal adenoma recurrence: a randomized intervention trial. Lancet 2000;356:1300-6.

66. Burchenal JH. Geographic chemotherapy-Burkitt's tumor as a stalking horse for leukemia: presidential address. Cancer Res 1966;26:2393-405. 


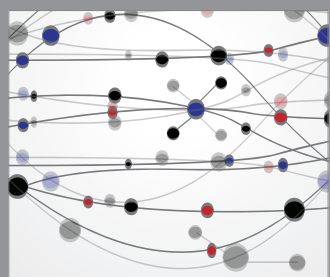

The Scientific World Journal
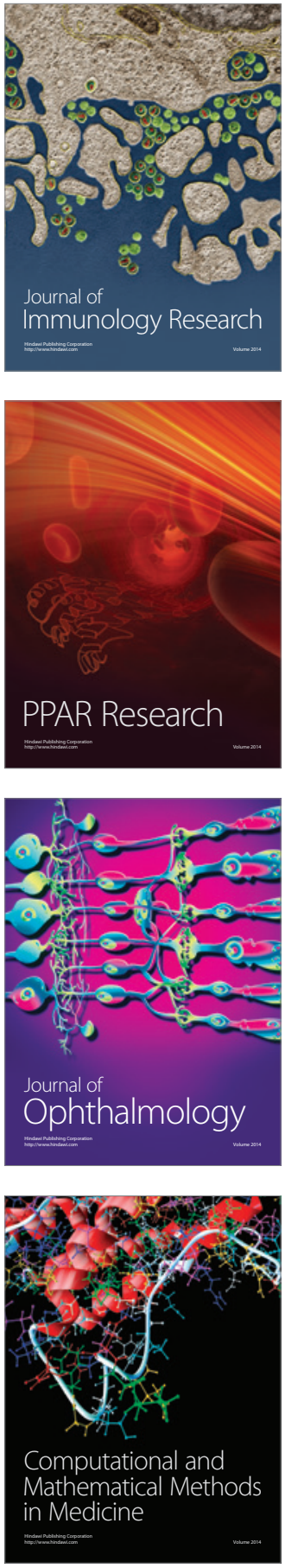

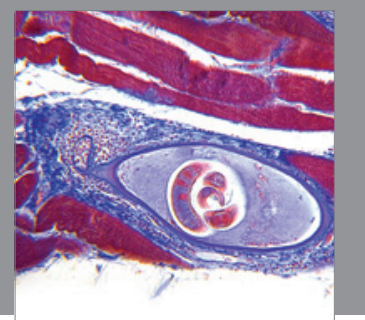

Gastroenterology

Research and Practice
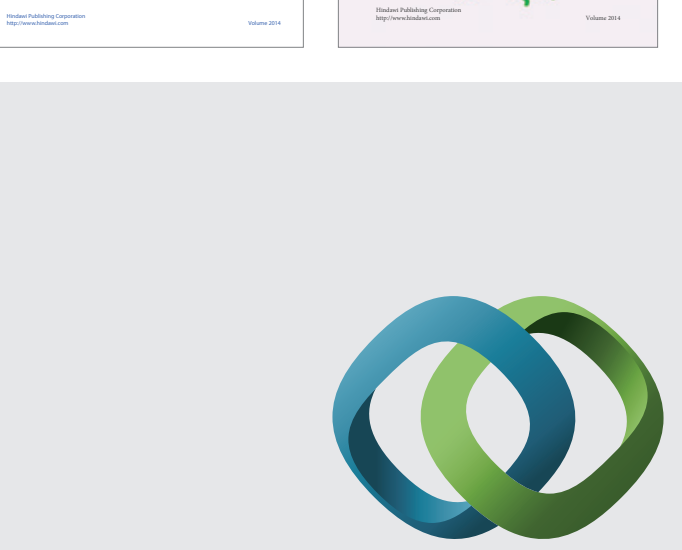

\section{Hindawi}

Submit your manuscripts at

http://www.hindawi.com
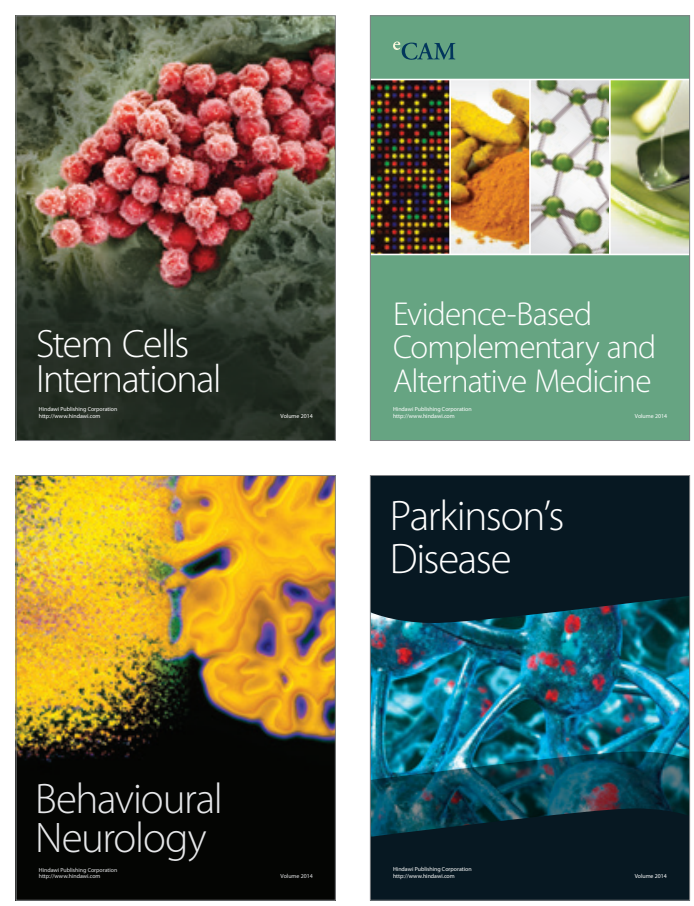

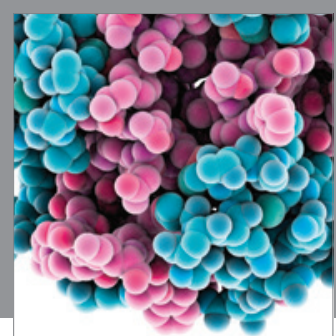

Journal of
Diabetes Research

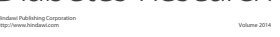

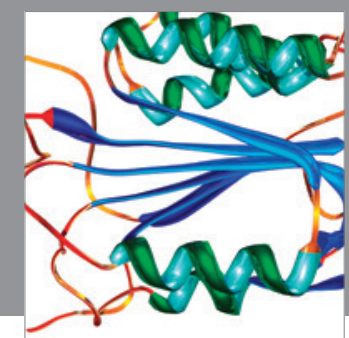

Disease Markers
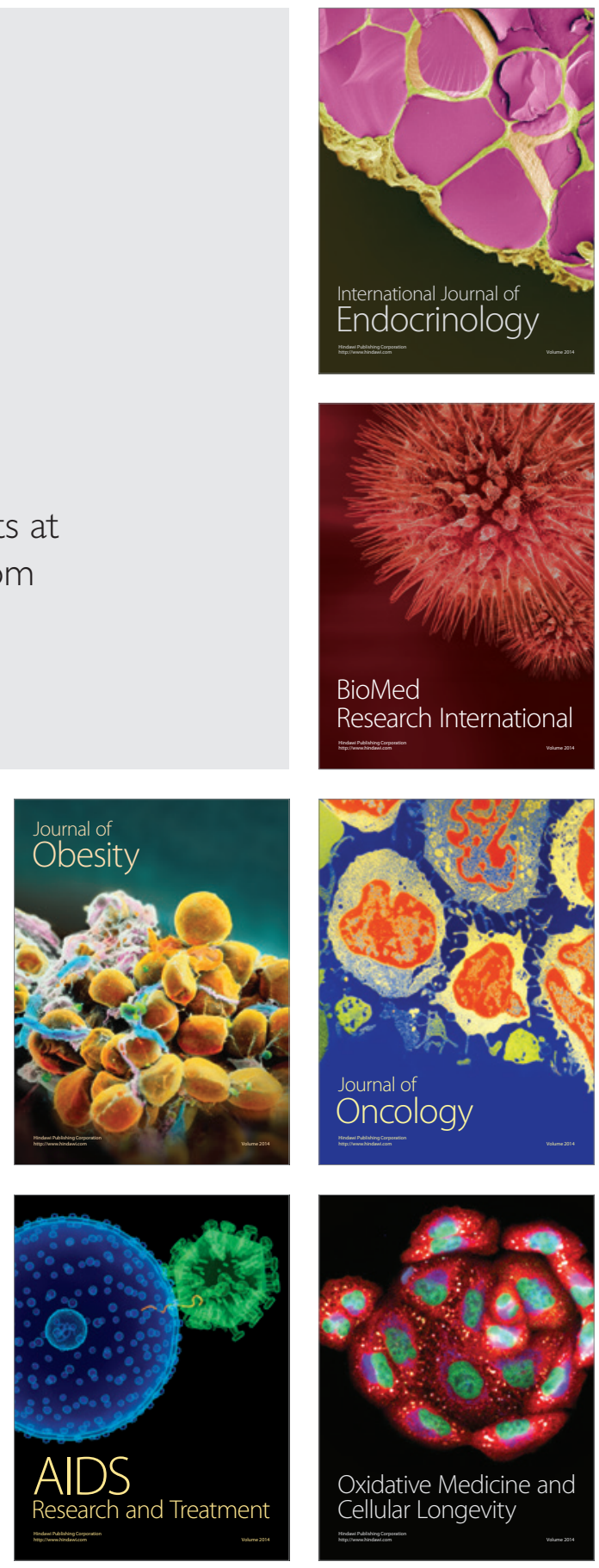